\section{MID TO LATE BRONZE AGE STRUCTURES (AREA G)}

Two adjacent circular structures (Structures 1G and $2 \mathrm{G}$ ) and one other possible earlier structure (Structure 3G) were identified in this area, along with three isolated features (Illus 32). Located to the north-east of the development area, these structures occupied a relatively flat piece of ground, with commanding views of the rest of the development site. The underlying geology was stony and sandy and this was generally reflected in the fills of features, which ranged from loosely compacted to firmly compacted sandy silts of light to dark brown.

Roundhouse Structures 1G and 2G were both post-built and bounded by an external ring groove. There was no evidence of an internal hearth in either structure but internal features were present.
Structure 3G comprised a group of features. Although an architectural form cannot be seen in plan, these features were all bounded to the south by a curvilinear gully suggestive of an enclosed area of activity. Three isolated features were also excavated, but their functions could not be determined.

The archaeological features represent at least two phases in the site history. The earlier phase is represented by the curvilinear gully and the later phase by Structure $1 \mathrm{G}$.

\subsection{Structure $1 \mathrm{G}$}

\subsubsection{General summary}

This was a post-built structure with a diameter of $c 11 \mathrm{~m}$. The structure was defined by a ring groove (034). It had an array of internal features and an entrance orientated to the south-east.

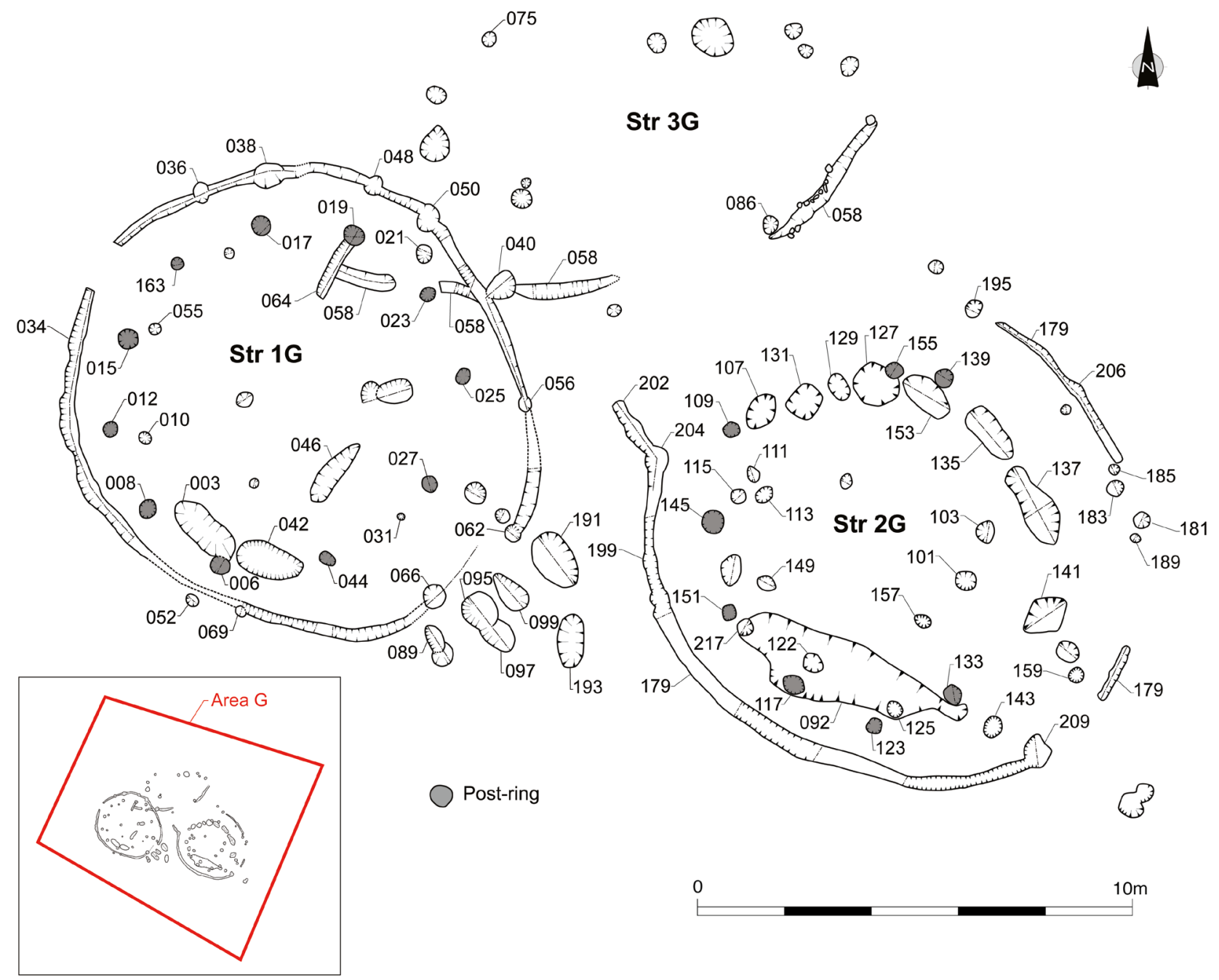

Illus 32 Area G site plan 


\subsubsection{Description}

The structure had a possible post ring of 11 post holes $(044,006,008,012,015,163,017,019$, 023, 025 and 027). All the post holes were filled with single deposits of sandy silts. Their dimensions ranged from $0.57 \mathrm{~m}$ by $0.6 \mathrm{~m}$ by $0.27 \mathrm{~m}$ deep to $0.32 \mathrm{~m}$ diameter by $0.06 \mathrm{~m}$ deep. Some of the other post holes close to this line, such as 010, 055, 021 and 031 , may represent a second post ring.

The ring groove (034) was a near-continuous cut filled with dark brown sandy silt (035). There were eight post holes within the ring groove, 036, 038, 048, 050, 056, 062, 066 and 069, each containing single fills of similar composition to the fill of the ring groove itself and suggestive of a single depositional event filling all of these features. Feature 052 may also have been a post hole within the ring groove, which now appears as an outlier because of the reduction in width of the ring groove due to horizontal truncation.

The ring groove had two breaks in it. The one to the north-west is interpreted as having been caused by truncation rather than being an entrance, because of the shallowness of the feature at this point and because a faint stain of fill material could be seen in the gap when the structure was exposed. The other break to the south-east was interpreted as the point of access, as Post Holes 066 and 062 appear to define the terminal ends of the ring groove, and the gap, which measured $2 \mathrm{~m}$, was thought to be an entrance. External to the entrance was a group of features (089, 095, 097, 099 (Illus 33b), 191 (Illus 33c) and 193). One of these, 097 , had been cut by a later feature (095 Illus 33a). These features may be the supporting post holes for a porched entrance to the structure. The number of features and their alignments may be as a result of several phases of porch structure associated with more than one phase of structure.

Several internal features within the house could not be assigned to the post rings. These features ranged in size from $0.15 \mathrm{~m}$ diameter by $0.1 \mathrm{~m}$ deep to $1.6 \mathrm{~m}$ by $0.8 \mathrm{~m}$ by $0.13 \mathrm{~m}$ deep. Two truncated pits, 003 and 042 , may be the vestigial remains of a larger ring ditch feature and they mirror a similar feature in Structure 2G. The remains of a short slot (064) cut an earlier feature (058, part of Structure 3G) and was cut by Post Hole 019.

Prehistoric pottery was recovered from within the fills of three features (012, 034 and 036) and burnt bone from within the fills of Features 017, 019, 042 and 064.

\subsubsection{Interpretation and phasing}

This appeared to be a multi-phase roundhouse represented by at least two post rings and a ring groove, none of which were necessarily contemporary with each other as there is no direct (33a)

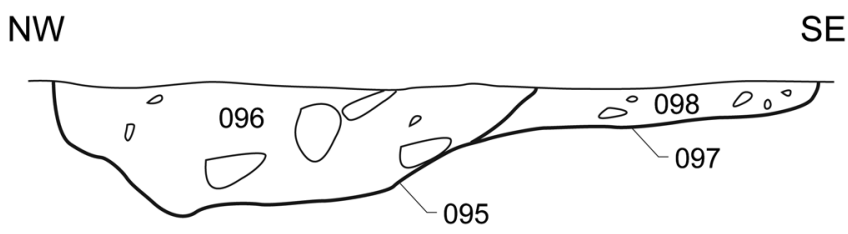

(33b)

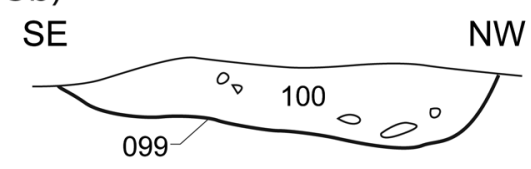

(33c)
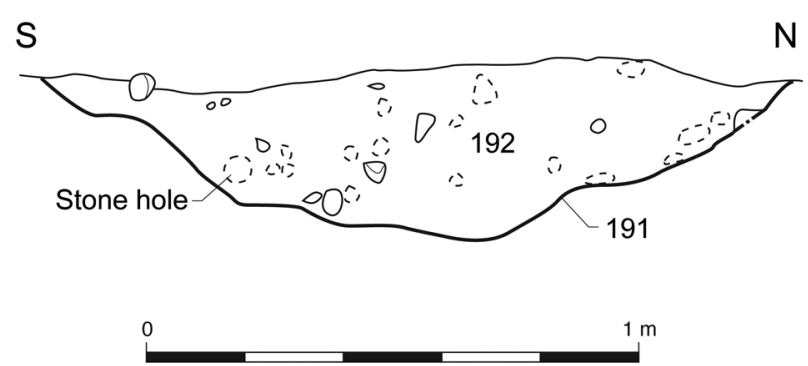

Illus 33 Selected sections within Structure 1G, Area G 
link between them. The features to the south-west of the structure, outside the entrance, probably represent a multi-phase porch structure associated with more than one construction phase.

\subsection{Structure $2 \mathrm{G}$}

\subsubsection{General summary}

This was a post-built structure with a diameter of $c 11 \mathrm{~m}$, the limits of which were defined by an outer ring groove. As with Structure 1G, there were internal features present and an entrance to the south-east.

\subsubsection{Description}

The post ring had eight surviving post holes (133, 123, 117, 151, 145 (Illus 34b), 109, 155 and 139), and adjacent post holes which may represent replacements $(125,122,149,217,115,111$ and (34a)

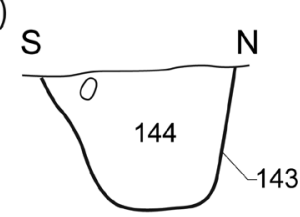

(34b)

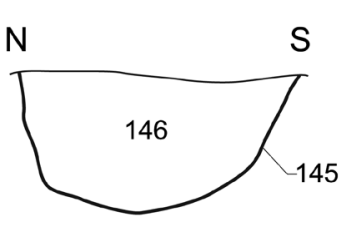

(34c)

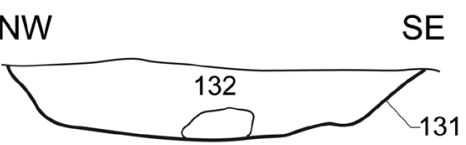

(34d)

(34e)
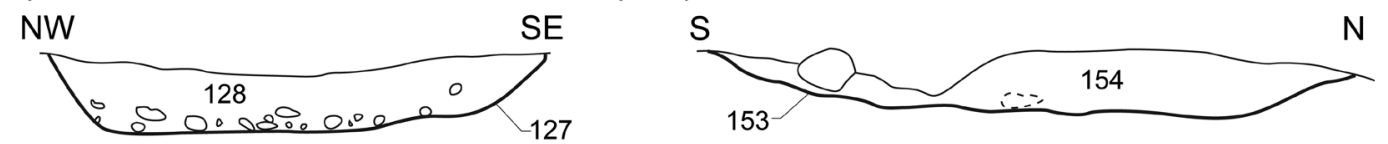

(34f)
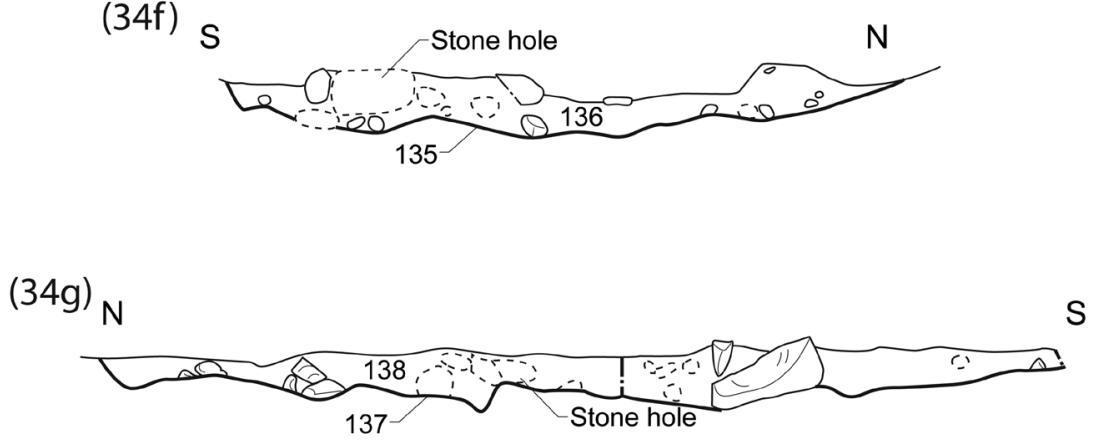

(34h)
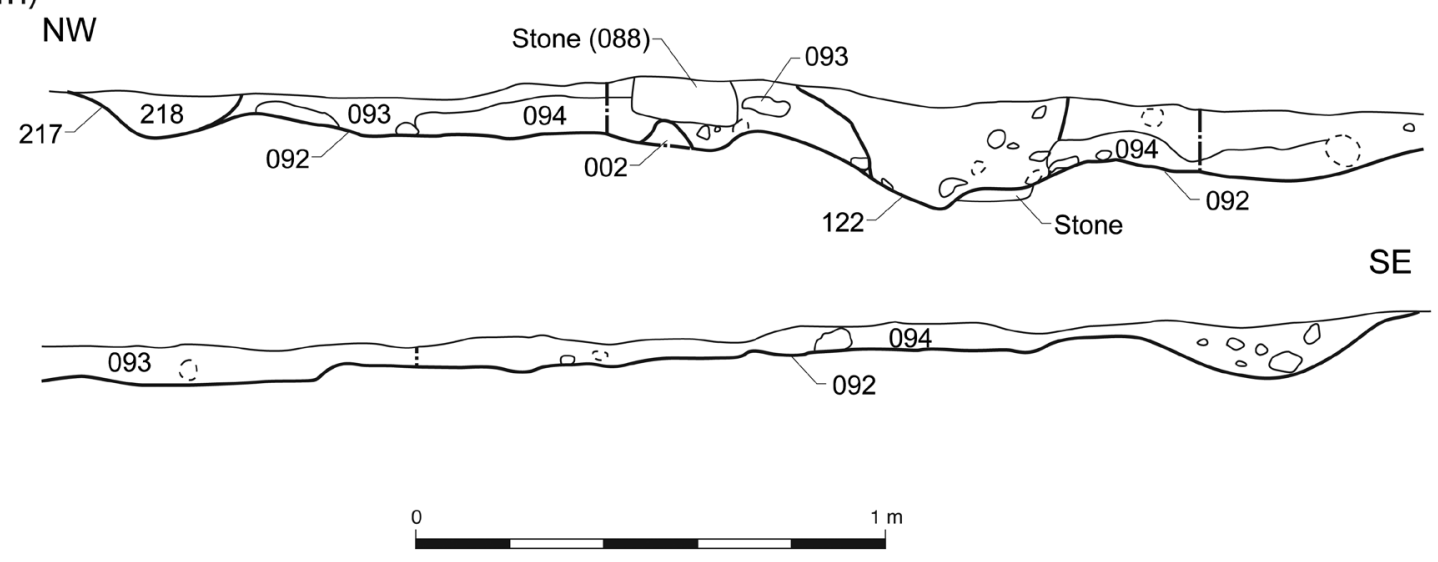

Illus 34 Selected sections within Structure 2G, Area G 
possibly 113). The main post holes were filled with single deposits of dark brown to black silt with charcoal inclusions, and the presumed secondary post holes were generally filled with dark to mid-brown silt with fewer charcoal inclusions.

The ring groove, 179 , had a diameter of $11 \mathrm{~m}$ and was heavily truncated, not being present on the north side of the house. The ring groove terminated at the south-east with Post Hole 209. To the north-west, a short section of trench, hinged on Post Hole 204, was orientated south-east/north-west and terminated in Post Hole 202. There were two post holes cut into the base of the ring groove, 199 and 206, and five other probable post holes which lay on the extrapolated line of the ring groove (195, $185,183,181$ and 189).

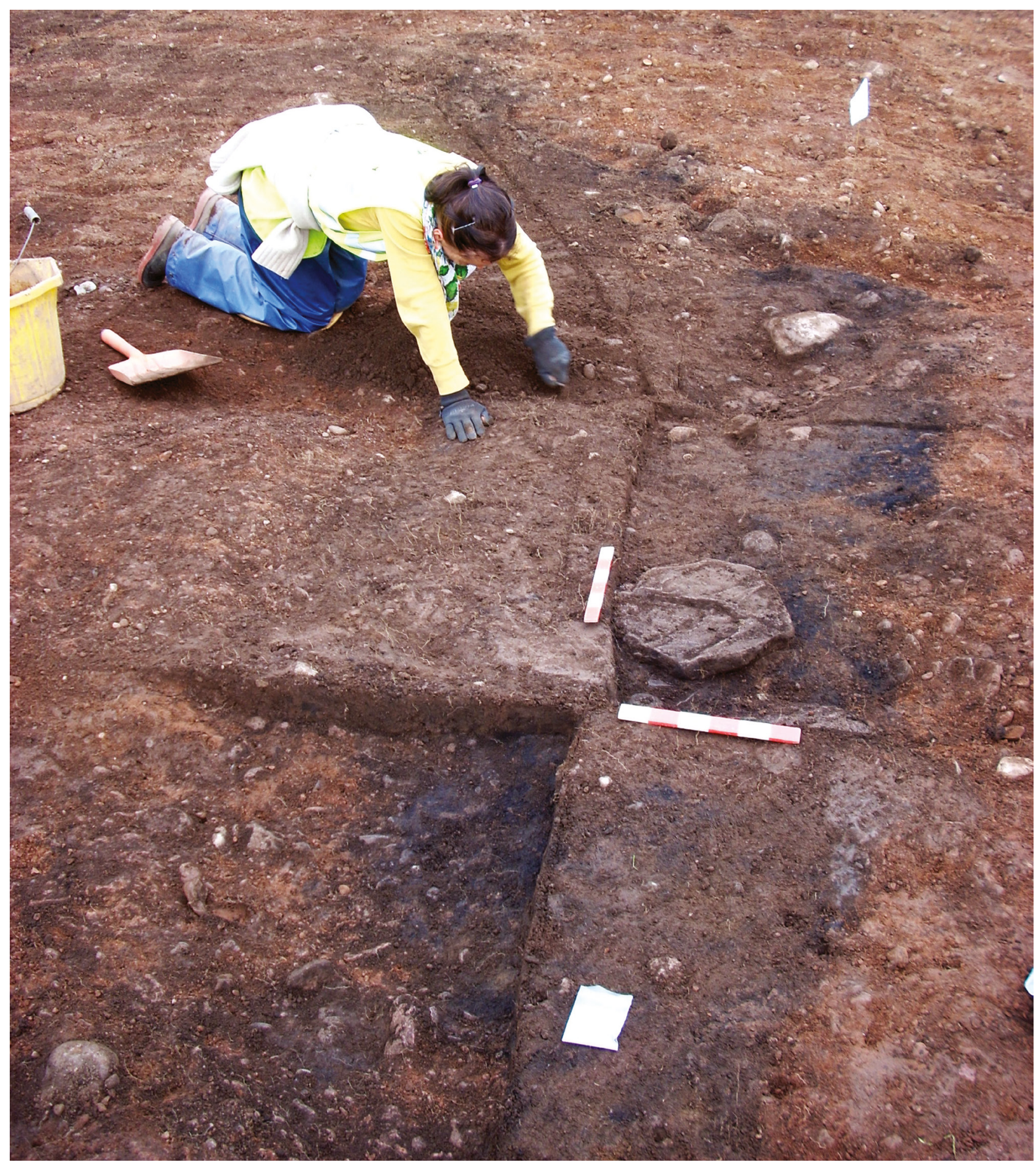

Illus 35 Excavating Pit 092 in 2G, Area G 
The $2 \mathrm{~m}$-wide entrance was orientated to the south-east, where there was a break in the ring groove. The entrance was defined by the terminal end of Ring Groove 209 and a corresponding break in the outer post ring between Post Hole 133 and Feature 141, as well as the positions of Post Holes 143 (Illus 34a) and 159.

An arc of eight pits $(107,131,129,127,153$, 135, 137 and 141 Illus 34c-g) ran concentric with the post ring on the north and east. Although they correspond with the outer post ring at a point where it is missing, it is difficult to assign these pits to the post ring because of their difference in size and form; they may represent a truncated ring ditch, corresponding with 092 on the south-west side. This would suggest that there are at least two phases to this structure, superimposed one on top of the other. Given that Post Holes 117 and 155 cut Ring Ditch 092 and Pit 127 respectively, it would appear that the post ring is later than the ring of pits.

Ring Ditch 092 (Illus 35) was also cut by 125, 122 and 217 of the arc of another possible post ring (Illus 34h), making the remains of putative Ring Ditch 092 earlier than this phase of occupation.

Three internal features (103, 101 and 157) formed a line and possibly represent an internal division, perhaps a windbreak across the porch.

Prehistoric pottery was recovered from within the fills of Features 125, 107 and 135, and burnt bone from within the fills of Features 092 and 141.

\subsubsection{Interpretation and phasing}

The main architectural features are at least two post rings, a ring groove and a ring ditch which possibly represents an earlier phase of occupation. There is evidence of a truncated and segmented ring ditch occupying the north and north-east, represented by an arc of pits, and the south and south-west represented by Pit 092 . Although almost identical, the radiocarbon dates (see below) indicate that this was a later building than Structure 1G.

\subsection{Structure 3G}

\subsubsection{General summary}

Structure 3G is represented by a grouping of 12 features to the north of the site which were bounded on their south by the intermittent remains of a curvilinear gully (058). The gully had two post holes cut into its base, 040 and 086 . If the curvature of Gully 058 is projected, and assumed to be a closed ring, then the feature would have an overall diameter of $c 15 \mathrm{~m}$. The curvilinear gully (058) was cut by the ring groove (038) of Structure 1G, making the former stratigraphically the earlier feature.

\subsubsection{Interpretation and phasing}

Stratigraphically this structure is earlier than Structure 1G, and therefore by inference earlier than Structure 2G. The structure consisted of a probable palisade, based on its size, and there was little evidence to suggest that there was a structure within this palisade. The palisade may therefore have formed a corral, or a windbreak to protect other kinds of activities from the elements.

\subsection{Artefacts}

\subsubsection{Pottery \\ Melanie Johnson}

A small MBA/LBA assemblage was recovered from this area, comprising 36 sherds from seven different vessels (P143-149). These were divided between Structure 1G and Structure 2G as follows: Structure $1 \mathrm{G}$ : nine sherds (377g, four vessels), Structure 2G: 27 sherds (271g, three vessels).

Eight of the sherds were recovered from contexts associated with Structure 1G (Post Holes 012 and 036, Ring Groove 034), while a further single body sherd was collected during cleaning over it. A small post hole forming part of the outer post ring of the structure (012) produced five flat base sherds weighing 330g (P143 Illus 36). The fabric was coarse, sandy and heavily gritted, up to $13 \mathrm{~mm}$ thick and the base had a diameter of $150 \mathrm{~mm}$. The sherds are possibly burnt and are abraded.

The other two features, the ring groove and Post Hole 036, which had been cut through the ring groove on the north side, contained three plain, very abraded body sherds with gritty fabrics. These are likely to be sherds relating to the occupation of the structure.

The remaining 27 sherds came from a post hole and pits within Structure 2G (107, 125 and 135). Pits 107 and 135 contained just four small plain body sherds between them. Post Hole 125 contained 


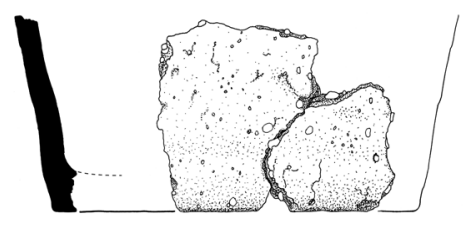

P143

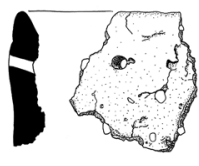

P146

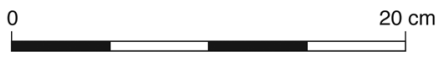

\section{Illus 36 Pottery from Area G}

23 rim and body sherds and a possible base (total weight 226g) from a vessel with a tapered rounded rim and thick body (P146 Illus 36), though little of the profile of the vessel survived. The walls were up to $14 \mathrm{~mm}$ thick, with finger-marking visible on both surfaces. The fabric was sandy and contained stones up to $10 \mathrm{~mm}$ in size.

It seems more likely that the larger deposits of sherd material recovered from Post Hole 012 in Structure 1G and Post Hole 125 in Structure 2G are the result of deliberate deposition rather than a process whereby residual small sherds worked their way into features during the occupation of the buildings. These deposits would have to have been made following the removal of any structural timbers from the post holes. Both of these post holes fall within the south-west quadrant of the roundhouse and form part of the post ring. Neither of these vessels had signs of surface deposits, unlike some of the other sherds from each structure.

\subsection{Environmental evidence}

\subsubsection{Calcined bone}

\section{Sue Anderson}

Thirty-three contexts contained $15.05 \mathrm{~g}$ of bone. Of this, 9.05g was collected from Structure 1G, $5.85 \mathrm{~g}$ from Structure $2 \mathrm{G}$ and $0.15 \mathrm{~g}$ from Structure $3 \mathrm{G}$. The largest group from Structure $1 \mathrm{G}$ was in Pit 042 (5.1g), and in Structure 2G there was a small concentration in Ring Ditch 092 (3.5g). One fragment from Linear Feature 064 in Structure 1G may be antler, and there was a fragment of a small petrous temporal (probably animal) in Structure 3G Post Hole 075.

\subsubsection{Charcoal \\ Michael Cressey}

Area $\mathrm{G}$ is low in charcoal overall and is represented by three individual fragments of hazel $(0.7 \mathrm{~g})$, with 80 fragments of oak $(8.6 \mathrm{~g})$ representing $92 \%$ of the assemblage.

\subsubsection{Charred cereal remains \\ Mhairi Hastie}

\section{Composition of plant remains}

The vast majority of the 93 samples from this area did not contain any carbonised material. Where plant remains were identified they consisted of very small amounts of poorly preserved cereal grain with occasional seeds of wild taxa, small abraded fragments of hazelnut shell and occasional charred rhizome fragments. No more than five identifiable items were recovered from any one sample. The majority of grains were identified as barley. Only one barley grain, recovered from a post hole $(010$, Structure 1G), was sufficiently preserved to identify the naked variety. Weed seeds were lacking, with only one seed of sedge being recovered from Post Hole 017.

\section{Distribution of plant remains}

Carbonised plant remains, including cereal grains and hazelnut shell, were recovered from features associated with Structure 1G and Structure 2G. The charred plant remains were found to be preserved in negative features, principally internal post holes and pits; only one external feature, Post Hole 089 to the south of Structure 1G, contained any carbonised remains. There was no general spread of plant remains throughout the different features and across the whole of the excavated area as seen elsewhere at Blackford. It would seem likely that in this case the plant material recovered from Structure 1G and Structure 2G is directly associated with occupation activities carried out inside the structures, particularly through food preparation and corn-drying, possibly at a central hearth. 
No plant remains were present in samples taken from Structure 3G. This lack of carbonised plant remains may indicate that food preparation was not being carried out in this structure. Nonetheless, this does not discount such crop-processing activities as winnowing, threshing or pounding being carried out in the structure, as the by-products of these activities would not be preserved in the archaeological record unless they came into contact with fire.

Looking at the spread of cereal grain and nutshell within the structures themselves, there is a distinct bias of plant material within internal pits and post holes which lie either against the wall of the structure, or form part of the house wall. Similar distributions of plant and other domestic remains are noted by Rothschild (1991) and Joyce \& Johannessen (1993). These ethnohistorical parallels record that domestic rubbish tended to accumulate around the edges of house structures, as central preparation areas were swept clean, and it is possible that the distribution of plant remains seen within Structures $1 \mathrm{G}$ and $2 \mathrm{G}$ may have resulted from similar processes, the internal space of each roundhouse being kept clean of debris, with burnt food remains being swept, along with other rubbish, to the side of the structure and producing an accumulation of material against the wall.

\subsection{Radiocarbon dates}

Eleven radiocarbon dates were obtained from charred cereal grains and nuts, six dates from Structure 1G and five from Structure $2 \mathrm{G}$ (Table 12; Illus 37). The dates reflect the period of transition from the MBA to the LBA. The dated material derived from the

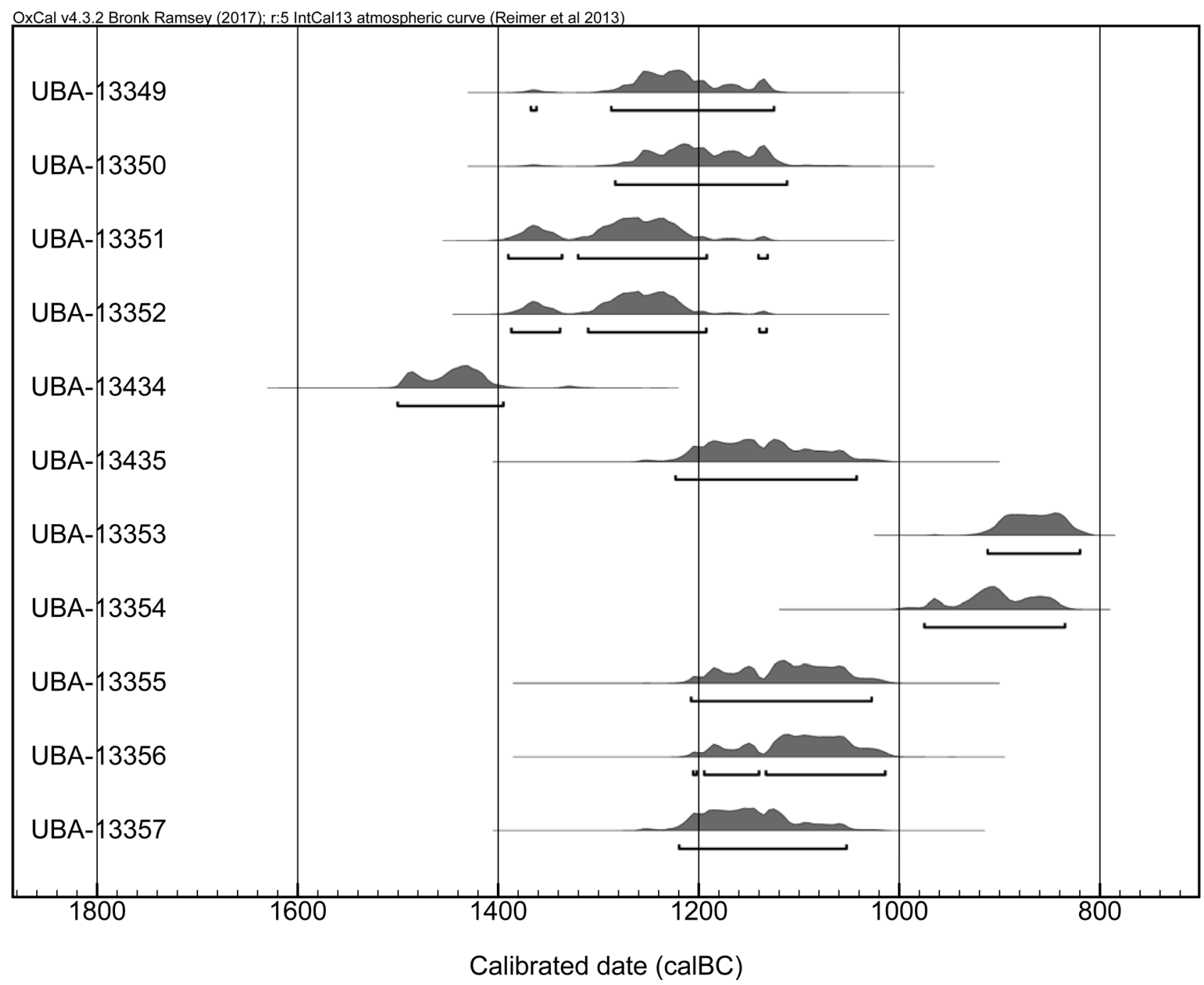

Illus 37 Radiocarbon dates, Area G 
single fills within post holes may have been caught within the post holes during the occupation of the site, or following rotting of the bases of the posts. Whether it entered the post holes in this way, or was incorporated following abandonment of the structures, the material is likely to have derived from the period of occupation, and therefore the occupation of the site would fall within the overall date range.

The two paired dates returned from Context 012 passed the chi-squared test and therefore could be legitimately combined giving an average age range of 1387-1135 cal вс (95\% probability; UBA-13351, UBA-13352).

The dates returned from Structure $1 \mathrm{G}$ are earlier than those returned from Structure 2G; from this it can be inferred that Structure 1G was built and occupied before Structure 2G. However, the very wide range of dates recovered from both structures suggests that there was some residual or intrusive material in both feature groups.

\subsection{Discussion}

\subsubsection{Phasing}

There are two recognisable phases across the site, the earliest represented by the curvilinear feature (058) of Structure 3G, the second by Structure 1G. Within the two more complete structures, other sets of intercutting features were identified which may represent episodes of repair and replacement or separate phases of construction.

Feature 058 was cut by the ring groove (034) of Structure 1G, but neither 058 nor 034 could be directly dated. However, radiocarbon dates returned from the post holes which formed the post ring of Structure $1 \mathrm{G}$ returned an overall date range between

Table 12 Radiocarbon dates, Area G. Calibration was conducted using OxCal v4.1.7, using the IntCal09 calibration curve

\begin{tabular}{|c|c|c|c|c|c|}
\hline Lab no. & Material & Context description & Date вр & $\begin{array}{l}95 \% \\
\text { probability }\end{array}$ & $\begin{array}{l}\delta^{13} \mathrm{C} \\
\% 0\end{array}$ \\
\hline \multicolumn{6}{|l|}{ Str $1 G$} \\
\hline UBA-13349 & $\begin{array}{l}\text { Hazelnut } \\
\text { shell }\end{array}$ & $\begin{array}{l}\text { Fill of Post Hole } 017 \text { in post } \\
\text { ring }\end{array}$ & $2992 \pm 24$ & $1367-1128$ вс & -23.5 \\
\hline UBA-13350 & $\begin{array}{l}\text { Hazelnut } \\
\text { shell }\end{array}$ & $\begin{array}{l}\text { Fill of Post Hole } 015 \text { in post } \\
\text { ring }\end{array}$ & $2978 \pm 27$ & $1312-1119$ вс & -24.7 \\
\hline UBA-13351 & $\begin{array}{l}\text { Hazelnut } \\
\text { shell }\end{array}$ & $\begin{array}{l}\text { Lower fill of Post Hole } 012 \text { in } \\
\text { post ring }\end{array}$ & $3022 \pm 27$ & $1389-1134$ вс & -23.6 \\
\hline UBA-13352 & $\begin{array}{l}\text { Hazelnut } \\
\text { shell }\end{array}$ & $\begin{array}{l}\text { Upper fill of Post Hole } 012 \text { in } \\
\text { post ring }\end{array}$ & $3020 \pm 25$ & $1386-1135$ вс & -25.5 \\
\hline UBA-13434 & Barley indet. & Fill of Post Hole 031 & $3165 \pm 28$ & $1498-1401$ вс & -22.1 \\
\hline UBA-13435 & Barley indet. & Fill of Pit 046 & $2936 \pm 27$ & $1260-1047$ вс & -24.7 \\
\hline \multicolumn{6}{|l|}{ Str 2G } \\
\hline UBA-13353 & Barley indet. & Fill of Pit 107 in poss ring ditch & $2726 \pm 22$ & $913-821$ вс & -30.1 \\
\hline UBA-13354 & Barley indet. & $\begin{array}{l}\text { Fill of Post Hole } 143 \text { in } \\
\text { entrance }\end{array}$ & $2764 \pm 23$ & $976-836$ вс & -30.7 \\
\hline UBA-13355 & $\begin{array}{l}\text { Hazelnut } \\
\text { shell }\end{array}$ & Fill of Pit 147 in poss ring ditch & $2919 \pm 23$ & $1212-1019$ вс & -31.6 \\
\hline UBA-13356 & $\begin{array}{l}\text { Hazelnut } \\
\text { shell }\end{array}$ & Fill of Pit 141 in poss ring ditch & $2911 \pm 24$ & $1208-1014$ вС & -28.0 \\
\hline UBA-13357 & $\begin{array}{l}\text { Hazelnut } \\
\text { shell }\end{array}$ & Fill of Pit 153 & $2943 \pm 24$ & $1259-1054$ вС & -30.9 \\
\hline
\end{tabular}


1498 вс and 1047 вс (95\% probability: Table 12); the curvilinear Feature 058 therefore would either pre-date or fall within this date range.

The date ranges obtained from the two structures overlap considerably. However, Structure 2G returned the latest dates from cereal grains (976-836 cal вс: 95\% probability, UBA-13354; 913-821 cal BC: $95 \%$ probability, UBA-13353). Whether these dates truly reflect the last occupation/abandonment phase of the site cannot be determined. The size, density and weight of a cereal grain means that they can be transported very easily, but also that they can sift through the fills of features, especially where the fills are loosely compacted, like those in Area G. Therefore the cereal may be intrusive and is not necessarily associated with immediate postabandonment infilling of these features.

It is possible that phases of both structures were occupied at the same time, depending on how the roofs are reconstructed. If the eaves are envisioned as extending to the ground then the structures could not have been contemporaneous, but if the eaves were cut short at the top of the wall then there would be enough room for both structures to have stood simultaneously. There was no evidence for outer ring grooves into which the eaves could have been secured, nor for drip-gullies associated with water run-off from the eaves of the roof. Alternatively, the structures may represent multi-phase use of the site, with each structure containing evidence for at least two phases of construction.

\subsubsection{Architectural features of the structures}

Both Structure 1G and Structure 2G indicate at least two phases of activity: a post-built structure and a ring groove structure with entrances on the south-east. Internally there were the remains of probable ring ditches which may or may not have been contemporary with one or other phase of occupation. The charcoal evidence indicates the use of oak and hazel. Oak was likely used for the structural components and hazel for hurdle panels.

The post ring in Structure 1G was relatively easy to define because of its completeness and the similarity in form and size of the post holes. The post ring in Structure 2G was more difficult to define, principally because of the arc of pits in the northern and eastern sides of the structure. These seven pits were inconsistent in size and form with the circular post holes identified as part of the post rings of both Structure $1 \mathrm{G}$ and Structure 2G. The pits contained no packing stones or post-pipes and did not display the expected profile of a post hole whose post was removed by dragging it out. It is unlikely that differential truncation across the site has resulted in such a disparity between these larger, shallower pits, and the smaller, deeper post holes. It is suggested then that these pits were not foundations for structural posts, even though they appear to follow and continue the arc of the outer post ring. More likely, these pits represent a truncated ring ditch with an undulating base. One of the pits, 127, appeared in plan to be cut by 155 , but during excavation the relationship was not clear. If, however, Post Hole 155 cut 127 then the post hole, and by extension the post ring, was later than the pit (127).

The distance between the ring groove and the post ring on the western side of Structure $2 \mathrm{G}$ was $1 \mathrm{~m}$ between 151 and 179 . Structure $1 \mathrm{G}$ was similar. The distance between Pit 135 and Ring Groove 179 on the east of Structure 2G was $1.5 \mathrm{~m}$, thus leaving enough space for the outer post ring to have continued between the pits and the ring groove.

Pit 092 in Structure 2G is best described as a shallow scoop ranging in depth from $c 0.08 \mathrm{~m}$ to $0.2 \mathrm{~m}$ deep, and was $2.1 \mathrm{~m}$ long. There were four features cut into its base, two of which (117 and 125) were sealed by 094 , the lower fill of 092 . Features 122 and 217 cut through both fills of 092 , therefore indicating that they are later in date than Pit 092 as it would have to have been infilled by the time they were cut. Post Holes 125 and 117 were sealed by deposits infilling Pit 092, indicating that they are either contemporary with or pre-date that pit, and form part of an earlier post ring.

The cut of Pit 092 was irregular and shallow and could easily be described as a wear pattern that post-dated the post ring, particularly as the subsoil was loosely compacted with a high proportion of sands and gravels. It is possible that these wear patterns/ring ditches are the product of livestock trampling, indicating that the building was at least partly used to stall livestock.

A similar situation can be seen with Pits 003 and 042 in Structure 1G, both shallow features. A post hole (006) appears to have cut the edge of 003, but 
it could also be argued that 003 had worn away and abutted the post hole, with the base of the posts still surviving as 003 became infilled post-abandonment. The adjacent pit (042) was deeper than 003 at $0.2 \mathrm{~m}$ and contained a higher percentage of stone within its fill than 003 . The sides of 042 were also steeper and appear to be the result of deliberate digging rather than wear. However, because of their proximity, and the irregularity in the ground surface making the edges of features indistinct, it may be argued that 003 and 042 were once conjoined, forming a pit similar in size and position to 092 in Structure $2 \mathrm{G}$. Both pits contained tiny fragments of burnt animal bone, which was likely derived from food processing.

Both structures had comparable ring grooves defining their extents. The ring groove of Structure $2 \mathrm{G}$ had a small slot on the north-west side that was orientated at an angle away from the rest of the feature, yet it appears to have been integral to the ring groove as it hinged on Post Hole 204. It is possible that the feature is the remains of foundations for an outbuilding, probably constructed from wattle hurdles, like the rest of the curtain wall that encompassed the structure.

The entrances to the two structures were orientated to the south-east. The function of the grouping of large pits outside the entrance of Structure $1 G$ was not determined but the teardrop shape of Pit 099 may represent the collapsed sides of a post hole, as the post was either pulled out or collapsed to the north-west. It is possible that these pits represent different phases of porch structure which are not entirely superimposed.

Structure 3G is defined by the curvilinear feature (058) and represents the earliest phase within Area $\mathrm{G}$. The feature was truncated to the south-east, making it impossible to determine whether there was an entrance in that sector. Projecting the alignment of the feature indicates that it would be sub-circular, measuring $c 15 \mathrm{~m}$ in diameter. At this size it is more likely to represent an enclosure boundary rather than a roundhouse wall. Potentially comparable MBA examples of circular structures enclosed by palisades at Blackford are Structures 3C, 1E and 3E.

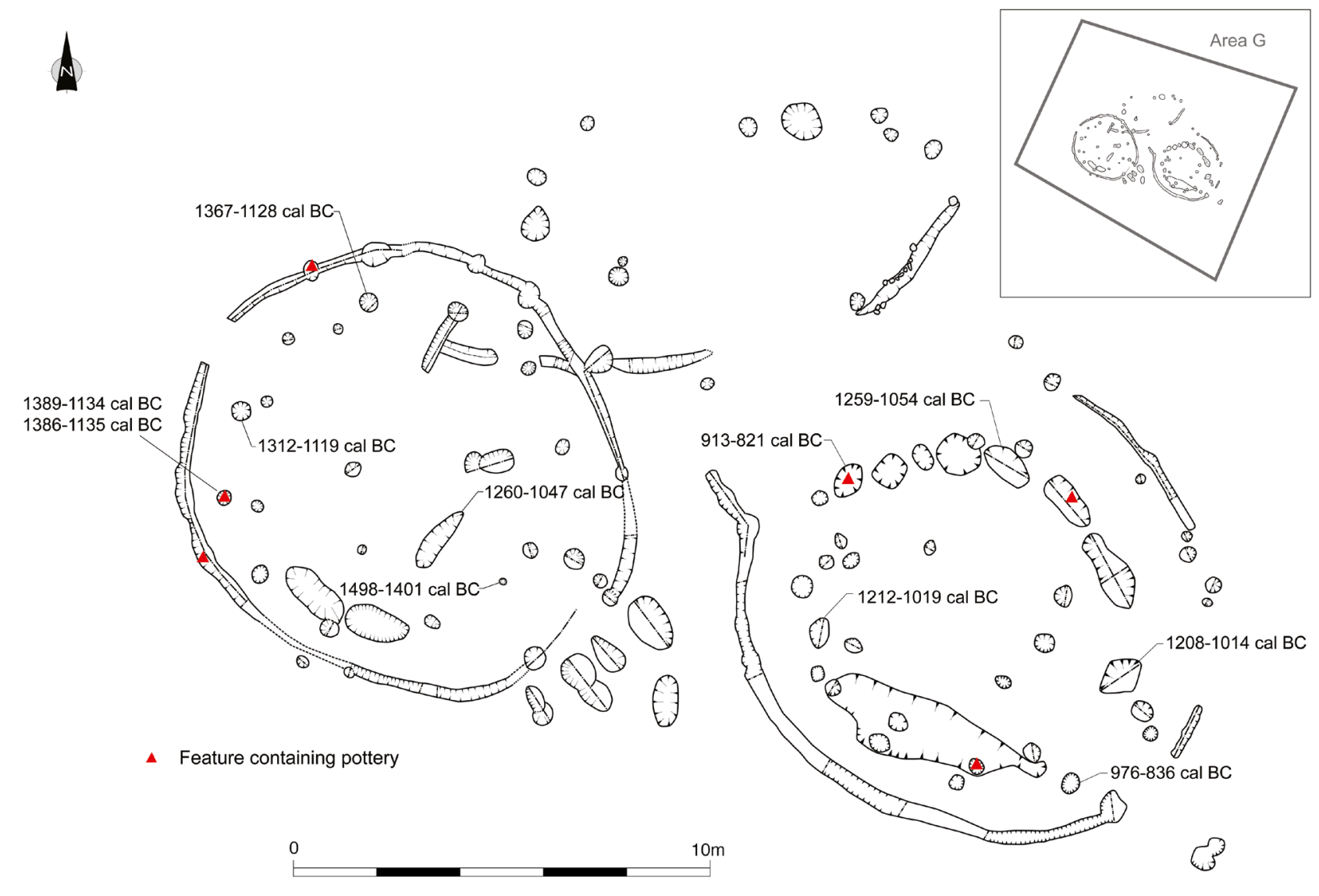

Illus 38 Finds and dating distribution plan, Area G 


\subsubsection{Finds distribution and taphonomy (IIlus 38)}

Johnson has suggested that the larger sherds of pottery found within structural Post Holes 012 and 125 may be the result of deliberate deposition after the posts were removed. Alternatively the sherds, possibly from an unused and broken pot, may have been used as packing material to secure the post in position. This is of course a pragmatic solution to the problem of securing posts; it does not rule out that there may have been a ritual component involved.

While the distribution of the cereal grains within the peripheral features of Structure $1 \mathrm{G}$ and Structure 2G could reflect house-sweeping episodes, the skewed distribution of the cereals may also be an artefact of the lack of internal features into which they could be transported. A similar taphonomic argument could be made for the calcined bone, the majority of which was retrieved from peripheral Pits 042 and 092.

\subsubsection{Structure use}

Structure 1G and Structure 2G both display structural elements associated with roofed buildings, ie the post rings. These rings of post holes are the likely foundations for upright posts, the function of which may have been to support a ring-beam. A ring-beam helps distribute the weight of a roof. Roofed structures potentially could have been used for a variety of purposes, including storage, animal byres, workshops and homes. There is no direct evidence that favours either of these alternatives. If hearths are taken as an indication of human occupation then there was no surviving evidence for one within either structure. Although Pit 046 in Structure 1G occupies a position where hearths are often found, there was no in-situ burning, and no deposits associated with activities in and around a hearth.

Indirect evidence of human occupation (and the presence of fire) within the structures comes from the distribution of the charred plant remains which, found in peripheral features, is argued by Hastie (see Section 6.5.3 above) to be a product of sweeping clean the central floor space of the house. The presence and distribution of prehistoric domestic pottery may also argue for human habitation. There was no evidence from these structures for craft specialisation. On balance, it is probable that these structures were houses.

\subsubsection{Economy}

There was very little evidence upon which to reconstruct the economic activities of the inhabitants of this site. The use of both domesticated and wild flora and fauna are attested to by the recovery of hazelnut shells, barley grains and probable deer antler. All of these products derive from food sources that could have been collected, grown and hunted. The fragmentary condition of the antler precludes a reconstruction of its use, although it may have been collected for working or to use as a tool. 